\title{
DETECTION OF “WALL THINNING” TYPE DEFECTS IN PIPELINES BY THERMAL METHOD
}

\author{
Roman OREL ${ }^{1, *}$, Sergey MESHKOV ${ }^{1}$, Volodymyr STOROZHENKO ${ }^{1}$, Aleksandr MYAGKIY ${ }^{1}$ \\ ${ }^{1}$ Department of Physics, Faculty ACT, the Kharkiv National University of Radio Electronics, Kharkiv, Ukraine
}

\begin{abstract}
A thermophysical model of a pipe with a local defect of the "wall thinning" type is developed. Calculations of thermal anomalies for pipelines with different parameters of hidden defects are performed, illustrating the possibility of using the thermal method of nondestructive testing. The conditions and methods of thermal control of individual sections of pipelines are specified. Thermal imaging examination of steam pipelines of the main condensate of the nuclear power plant was carried out. External factors that make it difficult to detect hidden defects (the influence of external lighting, cylindrical shape of controlled objects, powerful external heat sources) are analyzed. It was found that cavitation phenomena significantly increase the temperature drop in the locations of local defects. The possibility of using the thermal method of nondestructive testing for rapid detection of hidden defects such as "wall thinning" in the pipelines of the main condensate has been confirmed experimentally.
\end{abstract}

Keywords: Thermal control, Pipelines, Wall thinning, Cavitation phenomena, Hidden defects

\section{INTRODUCTION}

Pipeline equipment of various types is widely used in oil and gas enterprises and energy. After a certain period of operation, due to corrosion from the influence of the external environment, cavitation erosion, cracking of welding defects and deterioration of the material, defects arise in the pipes. According to statistics, the cause of more than $40 \%$ of explosions, industrial accidents and disasters is undetected hidden pipeline defects [1].

The thermal and mechanical stresses experienced by the pipeline equipment of various objects lead to a decrease in the thermal resistance of the metal, as a result of which the temperature on the surface of the equipment and pipelines rises. Therefore, temperature is an informative diagnostic indicator.

To solve the most important task of monitoring and diagnosing pipelines, it is necessary to search for new methods that would allow us to estimate the wall thickness for the subsequent replacement of critically damaged sections of pipelines. The use of contact diagnostic devices is very difficult due to the size and complex geometry of the objects under control or the difficulty of access to them. The complexity of the examinations can be significantly reduced by applying the thermal method of nondestructive testing. Due to its advantages, the thermal method can be used to control defects, such as sinks and thinning the walls of working high-temperature pressure pipes [2, 3].

The aim of the work was to build a thermophysical model of a pipe with a defect of the "wall thinning" type, to carry out appropriate calculations to determine the applicability of the thermal method for pipeline control and to experimentally verify the obtained calculation data at real objects.

*Corresponding Author: roman.orel @nure.ua

Received: 10.10.2019 Published: 16.12.2019 


\section{CALCULATION ON THE THERMOPHYSICAL MODEL OF A PIPE WITH A DEFECT}

To test the possibilities of detecting defects using the thermal method for various conditions and pipe options, a thermophysical model of a pipe with a local defect of the "thinning wall" type was built and tested. The diagram of the thermophysical model is shown in Figure 1. The object of control (OC) is presented in the form of a cylinder with heterogeneity (defect). The defect in the form of a wall thinning is modelled by a groove inside the OC, a depth $h_{\partial}$ and a size $l_{\partial}$.

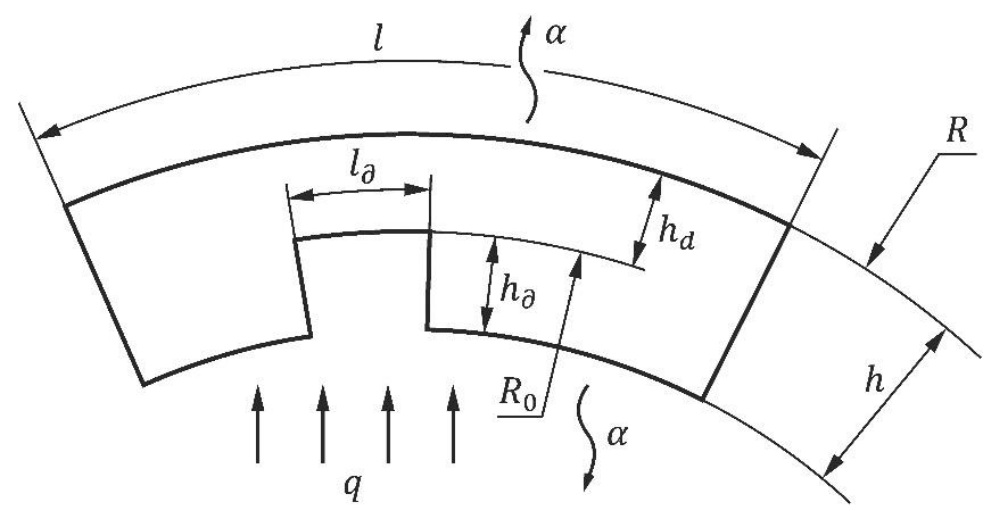

Figure 1. The object of control of the wall thinning of the pipeline

According to the proposed model, the solution of the non-stationary heat conduction equation $[4,5]$, which is a homogeneous linear differential equation of the second-order of parabolic type,

$$
\operatorname{div}(\lambda(\vec{r}, t) \nabla T(\vec{r}, t))+q(\vec{r}, t)=c \rho \frac{\partial T(\vec{r}, t)}{\partial t}
$$

carried out under boundary conditions of the 2 nd and 3 rd kind on the outer surfaces of the OC:

$$
\begin{gathered}
r=R_{0} ;\left.\left(\lambda(\vec{r}, t) \frac{\partial T(\vec{r}, t)}{\partial n}\right)\right|_{S}=\alpha\left(\left.T(\vec{r}, t)\right|_{S}-T_{e n v}\right)-q(\vec{r}, t) \\
r=R ;\left.\left(-\lambda(\vec{r}, t) \frac{\partial T(\vec{r}, t)}{\partial n}\right)\right|_{S}=-\alpha\left(\left.T(\vec{r}, t)\right|_{S}-T_{e n v}\right)
\end{gathered}
$$

where $T(\vec{r}, t)$ - temperature of OC, K; $T_{\text {env }}$ - environment temperature, $\mathrm{K} ; \lambda(\vec{r}, t)$ - thermal conductivity coefficient (in general, depends on temperature), $\mathrm{W} / \mathrm{m} \cdot \mathrm{K} ; q(\vec{r}, t)$ - heat flux density, $\mathrm{W} / \mathrm{m}^{2} ; \alpha$ - heat transfer coefficient, $\mathrm{W} / \mathrm{m}^{2} \cdot \mathrm{K} ; c$ - specific heat, $\mathrm{J} / \mathrm{kg} \cdot \mathrm{K} ; \rho$ - substance density, $\mathrm{kg} / \mathrm{m}^{3}$; $R_{0}$ - the radius of the defect, $\mathrm{m} ; R-\mathrm{OC}$ radius, $\mathrm{m} ; S$ - cell surface area.

The thermal conductivity of the defect is taken into account using the continuity condition at the boundaries of the defective region [6]:

$$
\lambda_{1}(\vec{r}, T, t) \frac{\partial T_{1}(\vec{r}, t)}{\partial n}=\lambda_{2}(\vec{r}, T, t) \frac{\partial T_{2}(\vec{r}, t)}{\partial n}
$$

It should be noted that in solving equation (1), the following expressions were used as initial conditions $\nabla T(\vec{r}, 0)=0$, and $T(\vec{r}, 0)=$ const $=293 \mathrm{~K}$. It is this equation that adequately describes the constructed thermo physical model (Figure 1) provided that it is solved with correctly selected boundary conditions (boundary conditions of the 2 nd and 3rd kind). Relations (2) and (3) reflect the 
real conditions of thermal flaw detection that is, heating OC with an external heat source and the presence of heat exchange with the environment.

The mathematical model of the process of thermal flaw detection is based on the solution of the differential equation of unsteady heat conduction written for a cylindrical coordinate system $[5,6,7,8]$ :

$$
\left(\lambda \frac{\partial^{2} T}{\partial r^{2}}+\frac{\partial \lambda}{\partial r} \frac{\partial T}{\partial r}+\frac{\lambda}{r} \frac{\partial T}{\partial r}\right)+\left(\frac{\lambda}{r^{2}} \frac{\partial^{2} T}{\partial \varphi^{2}}+\frac{1}{r^{2}} \frac{\partial \lambda}{\partial \varphi} \frac{\partial T}{\partial \varphi}\right)+\left(\lambda \frac{\partial^{2} T}{\partial z^{2}}+\frac{\partial \lambda}{\partial z} \frac{\partial T}{\partial z}\right)=c \rho \frac{\partial T(r, \varphi, z, t)}{\partial t}
$$

This problem is uniquely solved provided that it is possible to build a functional for thermal conductivity. For the three-dimensional case in our problem, this functional has the form [8]:

$$
\prod=\frac{1}{2} \int_{V}\left\{\lambda_{x}\left(\frac{\partial T}{\partial x}\right)^{2}+\lambda_{y}\left(\frac{\partial T}{\partial y}\right)^{2}+\lambda_{z}\left(\frac{\partial T}{\partial z}\right)^{2}\right\} d V-\int_{V} T q^{b} d V-\int_{S} T^{s} q^{s} d S-\sum_{i} T^{i} Q^{i}
$$

where $T$ - volume element temperature; $\lambda_{y}, \lambda_{x}, \lambda_{z}$ - thermal conductivity coefficients in the directions $x, y, z ; q^{b}$ - the amount of heat that enters the volume element; $T^{s}$ - surface temperature; $q^{s}$ - the amount of heat that is transmitted through a unit area; $T^{i}$ - temperature of additional internal sources; $Q^{i}$ - the amount of heat that is transferred from additional internal sources. We draw attention to the fact that the task is realized by the finite element method. For this, a space-time grid is constructed with a time step $\Delta t$ and coordinates respectively $h_{i-1}, h_{i}, h_{i+1}$ (Figure 2).

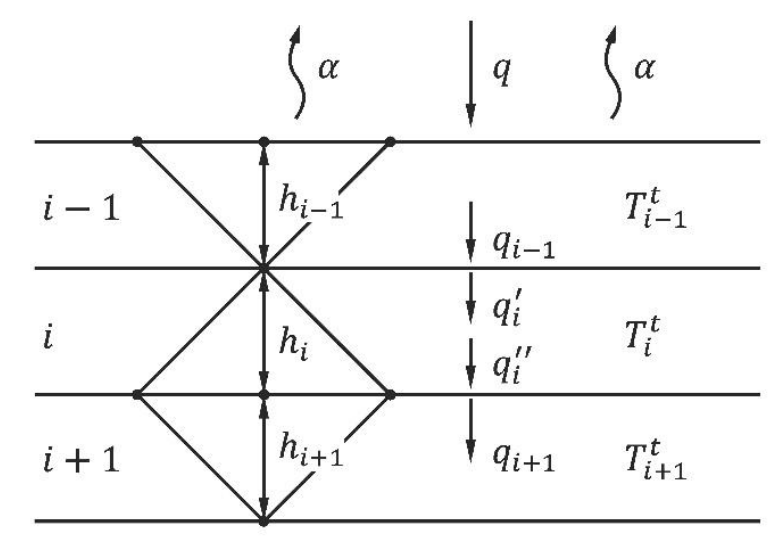

Figure 2. Scheme of the nodal grid, where $h$ is the coordinate along the polar axis; $T_{i}^{t}$ - temperature in the node $i$ at the time $t$.

According to the chosen method, equation (4) is approximated to the system:

$$
\begin{gathered}
\frac{\Delta t}{c_{i} \rho_{i}} \frac{2 \lambda_{i}}{h_{i}} \frac{\lambda_{i-1}}{\lambda_{i} h_{i-1}+\lambda_{i-1} h_{i}} T_{i-1}^{t+\Delta t}-\left(1+\frac{\Delta t}{c_{i} \rho_{i}} \frac{2 \lambda_{i}}{h_{i}}\left(\frac{\lambda_{i+1}}{\lambda_{i+1} h_{i}+\lambda_{i} h_{i+1}}+\frac{\lambda_{i-1}}{\lambda_{i} h_{i-1}+\lambda_{i-1} h_{i}}\right)\right) T_{i}^{t+\Delta t}+ \\
+\frac{\Delta t}{c_{i} \rho_{i}} \frac{2 \lambda_{i}}{h_{i}} \frac{\lambda_{i+1}}{\lambda_{i+1} h_{i}+\lambda_{i} h_{i+1}} T_{i+1}^{t+\Delta t}=-T_{i}^{t}-\frac{\Delta t}{c_{i} \rho_{i}} q_{i}
\end{gathered}
$$

where $\lambda_{i}$ - thermal conductivity coefficient in the grid node $i\left(\lambda_{i+1}-\right.$ in the node $i+1, \lambda_{i-1}-$ in the node $i-1) ; c_{i}-$ OC heat capacity in the node $i\left(c_{i+1}-\right.$ in the node $i+1, c_{i-1}-$ in the node $\left.i-1\right) ; \rho_{i}-$ OC density in the node $i\left(\rho_{i+1}-\right.$ in the node $i+1, \rho_{i-1}-$ in the node $\left.i-1\right) ; h_{i}-$ coordinate step size $h$ in the node $i\left(h_{i+1}-\right.$ in the node $i+1, h_{i-1}-$ in the node $\left.i-1\right)$, where the step can vary both linearly and 
logarithmically; $T_{i-1}^{t+\Delta t}$ - temperature in the node $i-1$ at the time $t+\Delta t ; T_{i}^{t}-$ temperature in the node $i$ at the time $t$.

Since the model is three-dimensional, the solution uses three components: radial $r$, angular $\varphi$, and coordinate $z$. When considering the propagation of heat flux in the radial direction, it is necessary to take into account the change in the geometric dimensions of the cell, since these dimensions depend on the distance to the $z$-axis [9]. For this, the heat transfer equation through one cell was used:

$$
\lambda \frac{\partial^{2} T}{\partial r^{2}}+\frac{\partial \lambda}{\partial r} \frac{\partial T}{\partial r}+\frac{\lambda}{r} \frac{\partial T}{\partial r}=\frac{1}{V_{i}}\left(q_{\text {in }}-q_{\text {out }}\right)
$$

where $q_{i n}=S_{i-1} q_{i-1}$ - heat flow that enters the cell; $q_{\text {out }}=S_{i+1} q_{i+1}-$ heat flow that leaves the cell, where $S_{i}=r_{i} \Delta \varphi_{j} \Delta z_{k}$ - square element; $V_{i}=r_{i} \Delta \varphi_{j} \Delta z_{k} \Delta r_{i}+\frac{1}{2} \Delta \varphi_{j} \Delta z_{k} \Delta r_{i}^{2}-$ i-th cell volume, where $\Delta \varphi_{j}$ - coordinate step $\varphi ; \Delta z_{k}$ - coordinate step $z ; \Delta r_{i}$ - coordinate step $r$.

For calculations, parameters were selected that correspond to real steam pipelines, in particular at nuclear power plants: the pipe wall thickness was $12 \mathrm{~mm}$ and $16 \mathrm{~mm}$, and the carrier temperature was $40{ }^{\circ} \mathrm{C}, 100{ }^{\circ} \mathrm{C}, 200^{\circ} \mathrm{C}$. Table 1 shows the results of calculations according to equation (1) for temperature differences $\Delta T$ for two variants of pipe thickness $h$, various disclosures of the defect $h_{\partial}$, and the depth of the defect $h_{d}$ (the continuous increment $\partial T$ is modelled by the difference $\Delta T$ ).

Table 1. The results of mathematical modelling of temperature differences $\Delta T$.

\begin{tabular}{l|c|c|c|c|c|c|c|c|c|c|c|c}
\hline $\begin{array}{l}\text { Pipe wall } \\
\text { thickness } h, \mathbf{m m}\end{array}$ & \multicolumn{9}{c|}{12} & \multicolumn{5}{c}{16} \\
\hline $\begin{array}{l}\text { Media temperature } \\
T_{c},{ }^{\circ} \mathbf{C}\end{array}$ & \multicolumn{3}{|c|}{40} & \multicolumn{3}{c|}{100} & \multicolumn{3}{c}{100} & \multicolumn{3}{c}{200} \\
\hline $\begin{array}{l}\text { Defect disclosure } \\
h_{\partial}, \mathbf{m m}\end{array}$ & 2 & 4 & 6 & 2 & 4 & 6 & 2 & 4 & 6 & 2 & 4 & 6 \\
\hline $\begin{array}{l}\text { Depth of occurrence } \\
h_{d}, \mathbf{m m}\end{array}$ & 10 & 8 & 6 & 10 & 8 & 6 & 10 & 8 & 6 & 10 & 8 & 6 \\
\hline $\begin{array}{l}\text { Temperature } \\
\text { difference } \Delta T,{ }^{\circ} \mathbf{C}\end{array}$ & 0.78 & 1.24 & 1.96 & 2.30 & 3.27 & 4.62 & 1,6 & 2.8 & 3.23 & 2.3 & 3.98 & 6.84 \\
\hline
\end{tabular}

An analysis of the calculated $\Delta T$ values compared with the upper limit of $\Delta T_{S}$ of the sensitivity threshold of modern thermal imagers $\left(\Delta T_{s} \leq 0.1-0.2^{\circ} \mathrm{C}\right)$ confirms the unconditional possibility of detecting defects such as "wall thinning" more than $10 \%$ of the wall thickness of the pipe in the absence of external factors.

\section{EXPERIMENTAL RESEARCH}

To verify the results obtained theoretically, studies were conducted on the pipelines of two blocks of the Zaporizhzhya nuclear power plant [10]. A number of objects were investigated, one of which was the main condensate pipelines. From the point of view of conducting thermography surveys, pipes represent a complex object. Even with a uniformly heated pipe and its uniform coating in enclosed spaces, effects arise due to a number of external factors, which greatly complicate the quantitative assessment of parameters of hidden defects $[9,11]$. 


\subsection{Methods and Conditions of Examination}

Thermal imaging survey was carried out in the premises at a temperature of about $30{ }^{\circ} \mathrm{C}$. The lighting of production areas consistent with the General principles, the main of which is to provide a uniform level of illumination. Place thermal imaging was chosen according to the scheme drawn up for different types of metallic wear of the working path TC K-220-44, which was a conditional card, based on the experience of operation of the investigated objects. Examination of the metal was performed in accordance with, PNAE G-7-008-89 "Rules of arrangement and safe operation of equipment and pipelines of nuclear power installations", and also on the basis of documentation for the thermal control method, research results and experience STC "Thermocontrol" of NURE. A thermography survey was carried out on pipelines without contact with the controlled object, without mechanical surface preparation and operating parameters of the equipment.

\subsection{Condensate Pipeline Research Results}

Hydraulic equipment is subject to cavitation erosion. Cavitation erosion is due to the phenomenon of cavitation that occurs in a moving fluid stream under certain hydraulic conditions. Erosive destruction of the surface during cavitation occurs as a result of repeatedly repeated hydraulic impacts of liquid jets on the surface (Figure 3).

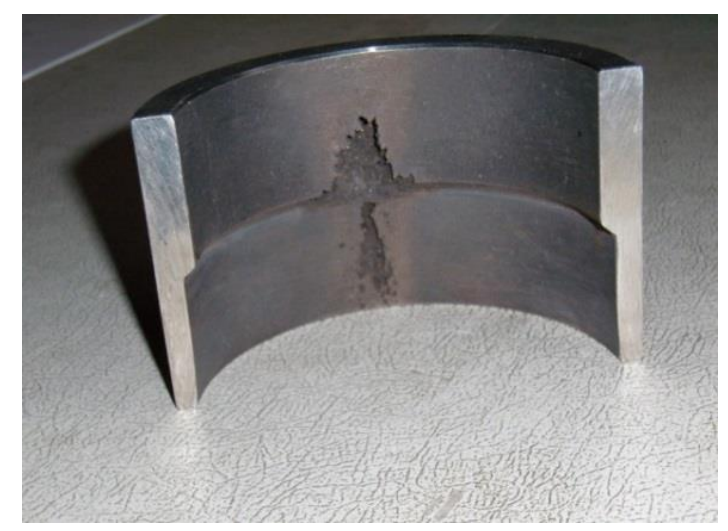

Figure 3. Fragment of a pipeline with a cavitation cavity (defect).

According to experimental facts, the rate of cavitation destruction of metal is 5,000 to 10,000 times faster than the rate of corrosion destruction. Although there is no generally accepted theory of cavitation, according to some estimates, the pressure peaks during compression (or destruction) of cavitation cavities reach $250 \mathrm{MPa}$, and the temperature reaches $10^{4} \mathrm{~K}[12,13]$. From this it follows that the places of formation of cavitation cavities are localized sources of elevated temperature, that is, at the locations of defects, cavitation phenomena introduce some additional increase in temperature on the pipe surface.

This assumption was confirmed when examining the pipelines of the main condensate with a carrier temperature of about $40^{\circ} \mathrm{C}$. The surfaces of the studied tubes were uniformly coloured and smooth, which brought them closer to Lambert emitters in terms of their emissivity.

The result of thermal imaging in closed rooms, when the temperature of the object is commensurate with the temperature of the surrounding air, is greatly influenced by external factors. As a result of their action, zones with an imaginary ("induced") temperature are formed on the surface of objects, which does not correspond to the actual radiation temperature of the object. In addition to quantitative 
temperature differences, such induced anomalies also had distinctive qualitative features. The main factors affecting the temperature fields of objects were identified and studied (shown in Table 2). For comparison, the result of temperature anomalies of detected defects in the pipelines of the main condensate is added to Table 2 .

Table 2. Qualitative and quantitative estimates of the influence of various factors

\begin{tabular}{l|l|l|r}
\hline \multicolumn{1}{|c|}{ Factor } & \multicolumn{1}{|c|}{ Qualitative differences, features } & \multicolumn{1}{|c}{$\begin{array}{c}\text { Temperature } \\
\text { Anomaly Levels }\end{array}$} \\
\hline 1 & Lighting & $\begin{array}{l}\text { The shape of the areas with imaginary temperature } \\
\text { follows the shape of glare from external light sources. } \\
\text { Temperature anomalies have a characteristic position and } \\
\text { depend on the location of the light sources. }\end{array}$ & $1.6 \ldots 1.9^{\circ} \mathrm{C}$ \\
\hline 2 & $\begin{array}{l}\text { The effect of the } \\
\text { cylindrical shape of the } \\
\text { surface of an object. }\end{array}$ & $\begin{array}{l}\text { Temperature anomalies are regular in nature and position } \\
\text { in the center of the object. The lower part of the pipe } \\
\text { has, as a rule, a lower temperature. }\end{array}$ & $1.0 \ldots 1.7^{\circ} \mathrm{C}$ \\
\hline 3 & $\begin{array}{l}\text { The influence of } \\
\text { powerful external heat } \\
\text { emitters. }\end{array}$ & $\begin{array}{l}\text { Near powerful heat sources, a narrow zone with elevated } \\
\text { temperature appears in the upper part of the control } \\
\text { object. The temperature anomaly has a characteristic } \\
\text { shape and position. Often a heat source enters the frame. }\end{array}$ & $0.9 \ldots 1.8^{\circ} \mathrm{C}$ \\
\hline 4 & Effect of room floor. & $\begin{array}{l}\text { The lower part of the pipe (to the axial) has a lower } \\
\text { temperature. Temperature anomalies have a pronounced } \\
\text { character and position. }\end{array}$ & $0.6 \ldots 1.0^{\circ} \mathrm{C}$ \\
\hline 5 & Defect & $\begin{array}{l}\text { The shape of the defective zone is not regular, its } \\
\text { position does not change when changing the shooting } \\
\text { angle. }\end{array}$ & $2.2 \ldots 2.9^{\circ} \mathrm{C}$ \\
\hline
\end{tabular}

As a result of research, several objects that have hidden defects were identified. Figure 4 shows a fragment of a pipeline with an identified zone of cavitation erosion.

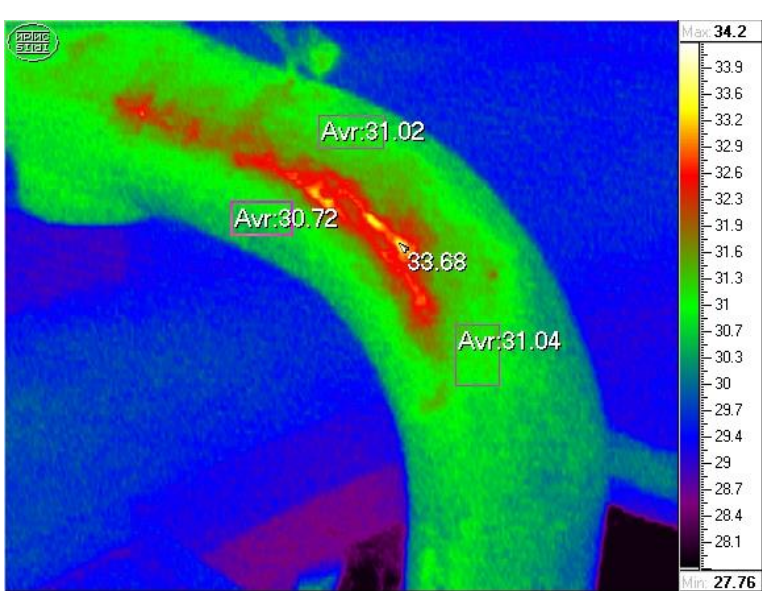

(a)

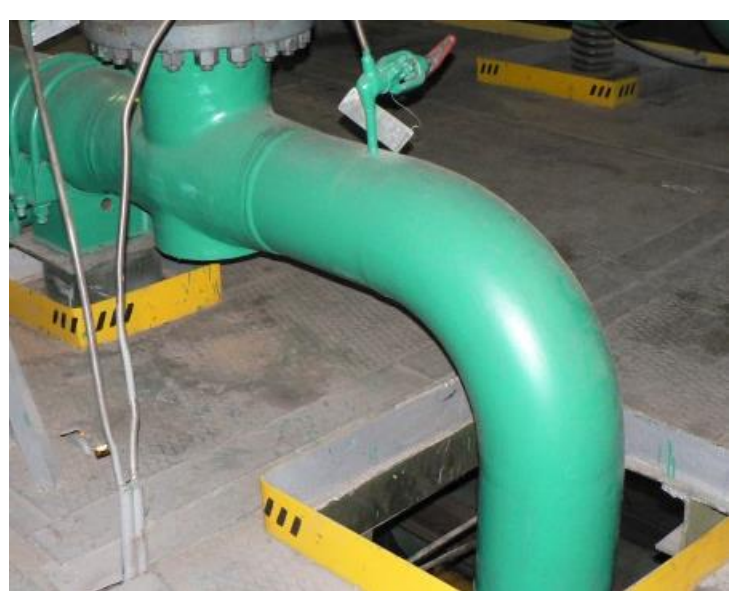

(b)

Figure 4. Identified zone of cavitation erosion (defect of wall thinning of the pipe): (a) Pipe thermogram; (b) Visible pipe image.

This defect was detected by the following symptoms: 
- the shape of the defective zone is not regular and differs from temperature distortions caused by the studied external factors;

- the position of the defect does not change when changing the shooting angle;

- the maximum temperature of the defect differs from the temperature of the rest of the pipe by

$2.7^{\circ} \mathrm{C}$, which exceeds the levels of other temperature anomalies (see Table 2).

In support of the fact of detection, it says that the detected defect is located at the turn of the pipeline, where there is a sharp deceleration of the condensate flow, and such places are most likely for cavitation cavities to occur. The result was confirmed by ultrasonic testing.

A comparison of the experimental results of thermal control with the calculation data by the thermo physical model shows that in the case of cavitation phenomena, the temperature of the wall thinning defects exceeds the calculated temperature by more than $60 \%$.

\section{CONCLUSIONS}

1. A thermo physical model of a pipe with a local defect of the "wall thinning" type was constructed, the use of which makes it possible to estimate the expected value of the signal from the defect with greater reliability.

2. The calculated data for the temperature difference in the defective areas are obtained, which allow us to confirm the possibility of detecting thinning defects more than $10 \%$ of the pipe wall thickness in the absence of external factors.

3. Field tests were conducted on pipelines, the results of which confirm the possibility of applying the thermal control method to detect hidden defects in pipelines at various oil and gas facilities and energy. In this case, the sensitivity of the thermal control method is much higher than the temperature anomalies of defects that pose a threat to the safe operation of pipelines.

4. An additional increase in temperature was found in the places of localization of defects during cavitation phenomena, which is an important result.

\section{ACKNOWLEDGEMENTS}

The authors are grateful to the staff of the South Ukrainian and Zaporizhzhya nuclear power plants for the provided samples and assistance in conducting research.

\section{REFERENCES}

[1] Khusnutdinova IG, Bashirov MG, Bakirov IK. Analysis of emergency situations due to the defects appearance in metal elements of shell-type structures in oil and gas industry. Problemy sbora, podgotovki i transporta nefti i nefteproduktov, 2017; 2: 155-164.

[2] Wright M. Sure2Grip-Quality assurance and structural evaluation of GRP pipes. In: The 9th European Conference on Non-Destructive Testing, Conference Proceedings, Berlin, 25-29 September 2006.

[3] Maldague X. Pipe inspection by infrared thermography. Materials Evaluation, 1999; 57: 899902.

[4] Nerazrushayushchiy kontrol': Spravochnik v 7 t. Pod obshch. red. V.V.Klyueva. T.5: V 2 kn. Kn. 1: Teplovoy kontrol'. Mashinostroenie, Moskva, 2004. 
[5] Storozhenko VA, Maslova VA. Termografiya $v$ diagnostike i nerazrushayushchem kontrole. Smit, Khar'kov, 2004.

[6] Vavilov VP. Infrakrasnaya termografiya i teplovoy kontrol'. Spektr, Moskva, 2009.

[7] Obbadi A, Belattar S. Characterization of delamination by a thermal method of non destructive testing. In: Proc. Vth International Workshop, Advances in Signal Processing for Non Destructive Evaluation of Materials, Quebec City (Canada), 2-4 Aug. 2005: 203-208.

[8] Tikhonov AN, Samarskiy AA. Uravneniya matematicheskoy fiziki. MGU, Moskva, 2004.

[9] Storozhenko VA, Myagkiy AV, Saprykin SA, Meshkov SN. Primenenie termograficheskogo metoda kontrolya dlya opredeleniya soderzhaniya zhidkoy fazy v gazoprovodakh. Metodi ta priladi kontrolyu yakosti, 2009; 23: 12-15.

[10] Meshkov SN, Orel RP. Faktory, snizhayushchie dostovernost' teplovizionnoy diagnostiki truboprovodov agregatnykh zalov AES. Visnik Natsional'nogo tekhnichnogo universitetu KhPI, Seriya: Elektroenergetika ta peretvoryuval'na tekhnika, 2018; 8: 39-44.

[11] Storozhenko VA, Meshkov SN, Gaptrakipov AA. Teplofizicheskoe modelirovanie protsessov vyyavleniya defekta $\mathrm{v}$ ob"ektakh tsilindricheskoy formy pri teplovom nerazrushayushchem kontrole. Tekhnicheskaya diagnostika i nerazrushayushchiy kontrol', 2004; 4: 37-40.

[12] Pirsol I. Kavitatsiya. Moskva, Mir, 1975.

[13] Nefedov YuI, Storozhenko VA, Bragin SS. Kavitatsionnyy energosberegayushchiy teplogenerator - gidrotaran. Energetika, Energosberezhenie, Energoaudit, 2011; 5: 9-14. 